The proposal is likely to be controversial for several reasons. First, many scientists who have been resentful of the privileged position and burgeoning budget of the cancer programme will not be happy to see the panel responsible for much of that growth placed in charge of the rest of NIH. In that regard, however, it should be noted that while Schmidt has skilfully fought for the interests of the cancer programme, he has also spoken out on many occasions against letting NCI's budget grow at the expense of other areas of NIH. A second factor is, however, potentially more disturbing. The establishment of a powerful committee to oversee the programmes of $\mathrm{NIH}$, though it will have no direct executive power, could seriously undermine the authority of the NIH Director. Though the present incumbent, Dr Donald S. Fredrickson, said in an interview last week that he would willingly work with such a panel if it is established, he would clearly not relish the thought of there being two Popes in charge of NIH and finding that he is the one in Avignon.

Another major point which the panel addresses is the confusion introduced into NIH planning by the repeated scraps between Congress and the Administration over the budget for the Department of Health, Education and Welfare, of which $\mathrm{NIH}$ is a part. Every year, Congress approves a larger budget for HEW than the president requests, and the matter becomes a political football with vetoes, budget deferrals and so on clouding the picture. Consequently, NIH frequently doesn't receive its budget until the fiscal year is nearly over, and it doesn't know until the last moment how much money is going to be available.

Fredrickson acknowledged last week that such uncertainties are a "very serious problem for NIH". But it is difficult to see a solution. Certainly, the panel's recommendations are unlikely to be accepted. The panel, in short, suggests that Congress and the Executive Branch should approve a new budgeting system for NIH which would allow forward funding of multiyear grants and contracts through a single appropriation instead of the present system under which new budgets must be approved each year. That system would, however, introduce more inflexibility into the federal budget, and would thus run counter to the desires of this Administration. The proposal, moreover, could just as easily apply to the rest of the Federal Government's $\$ 20,000$ million-a-year research budget, so the Administration would be wary of setting a precedent.

Finally, it should be noted that the strains within NIH and the rest of the biomedical research community have been less apparent in recent months. In part, that is due to the introduction of some new policies, such as a new granting arrangement in $\mathrm{NCI}$ to replace some contracts, and improvements in the quality of peer review of contract proposals. It is also due in part to the appointment last year of Fredrickson as NIH Director. A skilled administrator who has earned the respect of both scientists and politicians, Fredrickson has had a considerable calming influence. Nevertheless, many of the fundamental problems which have led to discontent in the past remain, and it is unlikely that the panel's pitch for more independence for NIH will solve them.

\title{
Human rights guidelines adopted
}

Colin Norman reports on moves in the United States to combat the repression of scientists

Following a recent spate of complaints that it has been too timid in speaking out against violations of human rights, particularly those of scientists, the National Academy of Sciences has adopted a set of guidelines to govern its actions when future infringements are brought to its attention. One of the Academy's most outspoken critics on such matters, Dr Jeremy J. Stone, Director of the Federation of American Scientists, last week welcomed the guidelines as offering a "constructive approach".

Proceeding from the observation that "violations of human rights . . . occur in many--perhaps all-countries", the guidelines suggest that the Academy should try to battle such violations by "persuasion on moral humanistic grounds". But they add that this approach "may require fortification by stronger measures".

The Academy operates for the US government a number of scientific exchange agreements with other countries, which gives Academy officials considerable contact with their foreign counterparts. In the past, the Academy has used such contacts to make private, face-to-face representations on behalf of beleaguered scientists, particularly repressed Soviet intellectuals. But only in the case of Andrei Sakharov has the Academy issued a public protest, and a number of scientists, both inside and outside the Academy, have recently criticised it for not speaking out more forcefully on other occasions.

The guidelines state that the Academy will continue to remonstrate influential officials in other countries, choosing individual cases of scientists and engineers to protest. "We will continue to use the quiet informal contact as our principal mode of communication with peer groups and governments in other countries", the guidelines state, but they add that "we d) not eschew entreaty by public vehicles; indeed, we anticipate that such action will occasionally be appropriate". The strongest leverage which the Academy has in such negotiations is the threat of withdrawal from participation in exchange agreements, and the guidelines recognise that such a measure is available. Indeed, "it is always implicit in the background, but (it is a measure) that we can use only rarely".

In a related development, Academy members adopted a resolution at the annual meeting last month affirming principles of freedom of inquiry and expression. They urged colleagues around the world to join them in sending the following (or similar) signed statement to the Academy:

I hereby affirm my dedication to the following principles.

- That the search for knowledge and understanding of the physical universe and of the living things that inhabit it should be conducted under conditions of intellectual freedom, without religious, political or ideological restrictions. That all discoveries and ideas should be disseminated and may be challenged without restriction

-That freedom of inquiry and dissemination of ideas require that those so engaged be free to search where their inquiry leads, free to travel and free to publish their findings without political censorship and without fear of retribution in consequence of unpopularity of their conclusions. Those who challenge existing theory must be protected from retaliatory reactions.

That freedom of inquiry and expression is fostered by personal freedom of those who inquire and challenge, seek and discover.

That the preservation and extension of personal freedom are dependent on all of us, individually and collectively, supporting and working for application of the principles enunciated in the United Nations Universal Declaration of Human Rights and upholding a universal belief in the worth and dignity of each human being."

An Academy official said last week that the Academy will act as repository for such statements and make public the response. Confidentiality will be guaranteed to those who request it.

Signed statements should be sent to the National Academy of Sciences, 2101 Constitution Avenue NW, Washington DC 20418. 